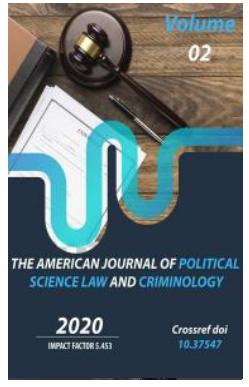

Copyright: Original content from this work may be used under the terms of the creative commons attributes 4.0 licence.

\section{The Influence Of The Energy Factor On Modern International Relations}

\author{
Mukhammadolim Mukhammadsidiqov \\ International Islamic Academy Of Uzbekistan Doctor Of Political Sciences, Associate \\ Professor 11, A.Kadiri, Tashkent, 100011, Uzbekistan
}

Abrar Turaev

Jizzakh State Pedagogical Institute, Uzbekistan Senior Teacher 4, Sh.Rashidov, Jizzakh, 130100, Uzbekistan

\title{
ABSTRACT
}

This article examines the theoretical and methodological aspects of the problem of energy security, which is becoming a topical geopolitical issue today. In particular, the interpretations of the concept of energy security, its transformation into a geopolitical factor and the structural elements of energy security are highlighted. The focus is on modern approaches and trends in energy security, as well as theoretical and methodological issues in the analysis of regional aspects of energy security.

At the same time, efforts will be made to reveal the scale of threats to energy security and the destructive factors that make energy security relevant, their impact on interstate relations and political destabilization. The article summarizes the author's definition of the concept of energy security.

\section{KEYWORDS}

Security, energy security, oil and gas, geopolitics, geoeconomics, region, Gulf, Central Asia, regional energy security, geoenergy, foreign policy

\section{INTRODUCTION}

In today's rapidly developing and globalizing world, one of the most fundamental and priority challenges facing a group of individual states or state is the problem of energy resources. Indeed, any modern technological system, production, military and civil transport, ensuring the vitality of the population and scientific laboratories, all industrial and agricultural sectors are based on energy supply, the specific political, economic and legal importance of energy resources is growing. 
At the same time, "Energy is the key to development, if necessary, the source. Today, if the energy sector does not develop, no industry or sector will develop. "Not only the manufacturing sector, but also many of the daily needs of humankind depend on energy in all its aspects, so this issue is now becoming an important geopolitical issue" (Karimov, 2006:106).

As a result of the increase in demand for energy on a global scale, scientific and theoretical research on the issue of energy security, its essence and coverage of its position in the overall security system has become an urgent problem. Because, in addition to traditional views on security, the scale of threats to all facets of social life shows the need for a general approach to the phenomenon of security.

In particular, the level of interdependence of security, political, ideological and economic spheres is very high today. In this regard, the urgency of the issue of energy security in the system of international relations and world politics requires an approach to it in general, especially in terms of political security. Experience has shown that, in general, "security" is a multifaceted phenomenon, but from time immemorial it has become a priority political feature, as it is focused on the integrity of society and the state and is realized through political power ( Jo'raev, 2007:110).

In addition, although not directly related to the political space, all areas and processes that require political influence and governance are included in the scope of political security ( Jo'raev, 2007:110).

Therefore, when studying the issue of energy security today, it is necessary to approach it in the context of general security in the coverage of its national and regional characteristics. If security stems from the "need for political management of public life" (Makeev, 1998:64) energy security should be recognized as a more geopolitical reality.

Currently, the concept of energy security is given economic, political and legal definitions. If we look at the history of the origin of this concept, on the eve of World War I, Churchill's historic decision to shift the power supply of British warships from coal to oil became important as a theoretical basis for energy security. Since that time, energy security has emerged as an important issue of national security (Yergin, 2006:81).

According to the analysis of the economic aspects of energy security, the concept of energy security first appeared in industrialized countries based on market economies in 1947 after the adoption of a normative document regulating state activities in the field of national security in the United States (Gafurov, 2010:178-182).

\section{METHODS}

In recent times, the concept of energy security has historically been shaped by the geopolitical competition of the world's major powers, and has become increasingly relevant in the context of resource price disputes between colonial Western energy importing countries and their colonies, such as OPEC (Organization of the Petroleum Exporting Countries). reached In response to the emergence of the Western world energy security system, there has been a merger of oil-exporting countries. And for them, energy security has become recognized as a concept that means that the economic interests of energy-supplying countries in foreign economic markets are protected and that they have full independence over national energy resources. As a result, importing countries have gradually developed collective 
energy security through the formation of large economic unions.

The following historical aspects should also be considered when considering the price of oil and gas resources and its politicization. In particular, energy security as an important element of national security was previously considered a major threat to a country's economic development, international energy policy and diplomacy, but now a new threat "energy terrorism". a direct threat to the oil and gas industry itself was also added. This, in turn, shows that the political aspects of energy security have been evident since the 1970s. The 1973 oil embargo was announced by the decision of the OPEC member states (UAE, Iraq, Kuwait and Saudi Arabia) and Iran. According to him, these countries intend to suspend oil supplies to the United States and the Netherlands and increase oil prices and reduce monthly production.

For example, on October 16, 1973, OAPEC members decided to increase the price of oil (Arabian light brand) from $\$ 3,011$ to $\$ 5,119$, or $70 \%$. In addition, nine Arab countries besides Iraq have agreed to a mutual agreement on the use of oil weapons. However, the global oil crisis of 1973 led to a split in the concept of energy security. The reason for this division is that the economic and political interests of oilimporting and exporting countries are formed on the basis of separate national energy policies. In particular, the energy security of resource-consuming countries has been explained by reasonable prices and stable supply of energy resources. In addition, there have been different interpretations of the concept of energy sovereignty of states in the field of energy security. This is due to the fact that the concept of energy security is interpreted differently by different state groups based on the scope of their interests. In particular, energy importing countries are interested in long-term and secure energy supplies at low prices. For exporting countries, energy security is to ensure the stability of energy supplies at high prices and support the efficiency of the oil and gas sector of their economy, to use the financial and economic potential of hydrocarbon production to build a modern economy(Jiznin, 2005:42-48).

\section{RESULTS}

In general, in modern research, energy security is largely recognized as an integral part of economic security. In the economic literature, the concept of energy security is classified through various complementary approaches. In particular, energy security means confidence in the supply of energy of the specified quality and quantity in the context of existing economic requirements. Energy security is a state of protection of vital energy interests of the individual, society and the state from internal and external threats. It can be seen that the definitions based on this approach mainly identify the objects of energy security. In another interpretation, energy security is a state of protection of the state, its citizens and society from threats to the sustainable energy supply of the economy. One of the key features of this approach is the ability of the energy system to withstand political, economic, man-made and natural internal and external threats (Gafurov, 2010:178-182).

Researcher A. Bereza explains the definition, which is close to the economic interpretation of the concept of energy security: it is a state of protection from external threats. " According to Robert Belgraf, a Western researcher, the focus is on energy-importing countries: "Energy security is the confidence of consumer countries and their governments to have robust energy supplies, production 
and sufficient energy resources to meet future demands" (Belgrave, Ebinger, Okino, 2000:2).

Another definition emphasizes price and supply: "Energy security is a reliable and adequate supply of energy at reasonable prices, a state of stable and uninterrupted supply that fully meets the needs of the world economy" (Bielecki, 2002:237).

\section{DISCUSSION}

Based on different approaches to energy security, the essence and geopolitical aspects of energy security can be explained through the following four main conceptual parts:

- Energy reserves, including oil and gas resources;

- Price;

- Reliable supplier;

- Safe transportation.

Energy reserves, especially oil and gas resources, are a key and primary component of energy security. Recognition of energy security in terms of the depletion or depletion of oil and gas resources is equally important for exporting and importing countries or groups of countries. In particular, the growing demand for energy resources of developing countries in the world has created competition to fight for the resources of oil and gas reserves. The political importance of energy has further increased as a result of the alarming forecasts of major research centers and well-known analysts. The main sources of world energy are oil, natural gas, coal, nuclear energy and hydropower. According to the International Energy Agency, they meet 90\% of global energy demand. Specifically, global consumption of solid hydrocarbons is growing by $1-2.5 \%$ per year. In general, in the coming decades, the energy needs of the world community will be met by major primary sources ( Borovskiy, 2008).
According to sources, by 2030 the share of oil in global energy consumption will be $38 \%$. At the same time, the demand for natural gas will almost double compared to 2001 and will account for $30 \%$ of the energy market (Kalicki, David, 2005:25).

As a result of these predictions, a sharp political struggle has arisen for the ownership of primary energy sources, in particular oil and gas reserves, and their unimpeded use. As a result, there is a tendency to politicize the issue of energy security and the use of oil and gas reserves as political pressure. Well-known Russian scientist A. Kokoshin noted that today in international political relations there is enough experience in the use of raw materials for both positive and negative purposes (Kokoshin, 2006:80).

Of course, it is no secret that such concerns are of greater concern to consumer states. In particular, countries have different capabilities in terms of oil and gas reserves. For example, the Middle East, especially the Persian Gulf region, is recognized as the region richest in oil and gas resources. The countries in the region account for $61.5 \%$ of the world's oil reserves and $40.5 \%$ of natural gas.

Saudi Arabia alone has $25 \%$ of the world's oil reserves, which highlights the country's importance in global energy policy. Or Russia, Iran and Qatar alone have $70 \%$ of the world's gas reserves (Harris, 2010:169).

According to British Petroleum, the Gulf Cooperation Council states, along with Iran and Yemen, own $50 \%$ of the world's proven oil and $40 \%$ of gas reserves so far. It accounts for $28 \%$ of world oil exports and $12 \%$ of gas exports. Central Asia's proven natural gas reserves, estimated to be $230-360$ trillion cubic feet, are about 7\% of the world's energy reserves (Sentralnaya Aziya - 2010:29). 
In general, in the context of global competition for oil and gas reserves, which is a key element of energy security, the main focus is on resource ownership. At the same time, the strong focus on oil and gas-rich regions, the establishment of effective and strong cooperation with countries rich in oil and gas resources, and geographical rapprochement demonstrate the geopolitical aspects of energy security.

Some researchers acknowledge that the concerns of the media and experts about energy crises in recent years, the lack of hydrocarbon reserves, and the crisis over finding alternative sources have not been fully substantiated. The root of the problem is not with the depletion of underground resources, but with the reality on the ground, that is, with politics.

The geopolitical aspects of energy security in the oil and gas sector are becoming more pronounced, especially in energy-rich regions, as a result of the escalation of conflicts of interest between major powers. A number of trends in the global energy market, in particular, the growing level of global energy consumption, energy competition is becoming a form of regional conflict, the geopolitical features of the energy system are becoming more pronounced as a result of countries' efforts to form energy alliances. As a result of the growing dependence of economic development on energy resources, the interest and influence of the world's countries on hydrocarbon-rich regions is growing. This is due to the fact that the modern international and national energy policy of states is based not on the recognition of values such as good neighborliness, common interests and adherence to international law, but on the specifics of development and geopolitical imperatives of national interests. Therefore, the issue of mutually beneficial cooperation with developed countries with oil and natural gas reserves, fuel and energy complex is very important from a geoeconomic, geopolitical point of view (Juraev, Kasimova, 2008:223).

Price - High prices always enrich oil-producing countries. Consumer countries, on the other hand, will be able to continue their efficient economic activities without certain barriers only if they are able to meet their energy needs at reasonable prices. In this regard, the concept of energy security in the oil and gas sector applies not only to the increase or decrease in the volume of reserves, but also to the increase or decrease in the price of oil and gas resources. Especially in most developed and developing countries there is a problem of energy dependence. One of the main priorities of the foreign policy of such countries is to import oil and gas resources at reasonable prices and to establish mutually beneficial cooperation with exporting countries.

According to the data, world oil demand has increased by 7 million barrels per day at the beginning of the last decade. The rapid growth of demand is due to China, India, Japan and European countries, whose economic development has been rising in recent years. China alone imports 3 million barrels of oil per day. This figure is almost half of China's total consumption ... Although its share of the world oil market is around $8 \%$, its share in the growth of total demand in the post-2000 period is 30\%. If in 1970 North America consumed twice as much oil as Asia, and in 2005, for the first time, Asian oil consumption exceeded that of North America .... Half of the increase in oil consumption over the next 15 years will be in the Asian region. It should be noted that at a time when China's share of world oil consumption does not exceed $8 \%$, the United States consumes $24 \%$ of the world's oil production. 
This trend certainly indicates that oil prices are rising. In particular, the rise of oil prices to \$ 147 in the summer of 2008 led to new approaches to energy security and increased competition for hydrocarbon resources. While this tension is unknown at first glance due to the global financial crisis, competition is also intensifying as economic development becomes more dependent on energy resources. Reflecting on the specifics of modern world energy policy, researcher Stuart Harris argues that one of the three most important aspects of energy policy is the end of the cheap oil era (Harris, 2010:166-173).

According to Russian energy researcher Yuri Borovsky, the main indicator of the crisis in the global energy market is high prices.

In this regard, another Russian expert, S. Milov, believes that the level of prices for key global energy resources is a factor in the redistribution of economic and political influence in the world. He cites the following arguments to substantiate his opinion: As a means of global influence, oil prices are an important weapon in the hands of exporting countries - primarily the Middle East. Leading among them are Saudi Arabia and Iran; Leads to new conflicts in the international arena between developed importing countries over the struggle for control over energy resources (Milov, 2004:23).

Although researchers say that oil and gas resources are becoming a political weapon, efforts are being made to create a modern international energy security system, and certain dialogues are being formed between oil and gas exporting countries on quotas for oil and gas production and refining.

A reliable supplier is an important component of energy security and in many respects is the most important subject in the foreign policy of consumer countries. Ensuring supply stability is not only measured by the volume of oil and gas reserves. Perhaps the extraction of sufficient reserves and their delivery to the consumer is also important in the energy security system. Today, the energy needs of the developed countries of the world are met by the Gulf, Caspian and Central Asian and North African countries. Because oil and gas reserves in these regions have enough weight for export.

It should be noted that one of the important factors of reliable supply in ensuring energy security is the availability of a favorable investment climate. According to the International Energy Agency, \$ 17 trillion will be needed to develop the world's energy system over the next 25 years (Yergin, 2006:81).

It is estimated that increasing global energy production will require an additional investment of $\$ 16$ trillion or $\$ 568$ billion per year in the energy sector from 2003 to 2030. About half of this investment should go to energy in developing countries. The reason is that the demand for energy and production in these countries is growing rapidly. In today's energy policy environment, the Gulf states are interested in the guarantee of sustainable reserves and the sustainability of sustainable supply. Therefore, the Gulf states are trying to attract large investments in this area to strengthen their ability to meet the needs of international energy consumers.

One of the main challenges facing countries in the regions "responsible" for global energy supply is to attract additional investment in the oil and gas sector, increase and diversify opportunities for regular supply. Undoubtedly, the issue of diversification alone will be the main fundamental principle of energy security in oil and gas. Therefore, as a result of uncertainty about the availability of 
sufficient oil reserves in the Caspian Basin and Central Asia, the persistence of instability in Iraq is leading the West to recognize the Gulf states as alternative energy suppliers. What is clear is that the new energy policy of the Middle East will depend on changes in supply and demand in the world energy market.

In addition, the geopolitical competition of a number of countries in the oil and gas-rich regions also has a negative impact on global energy supply. For example, the policies of the leading countries towards the countries in the Persian Gulf region show one-sided interests. While ensuring the security of the Persian Gulf region is firstly of interest to the countries of the region, secondly, the Gulf is also very important for the Asian countries that are still dependent on energy resources. In this regard, the energy potential of the region cannot be imagined without the state of Iraq. Because Iraq owns $11 \%$ of the world's total oil reserves. The overthrow of the regime in Iraq and the subsequent period limited the opportunities for the effective use of Iraq's oil potential.

Energy security in the Persian Gulf region is also directly linked to Iran. Iran owns $7 \%$ of the world's mineral resources and $10 \%$ of its oil reserves. It also ranks second after Russia in terms of gas reserves. Its location in the heart of Eurasia and its rich oil and gas reserves are the basis for its recognition as a subject at the center of global energy policy. Effective use of existing opportunities, becoming a reliable supplier and ensuring international energy security in the future is a key issue in the world community's attention, which requires Iran to be more involved in international and regional energy cooperation processes. The implementation of the Iran-Pakistan-India gas pipeline project or the European Nabucco project is in line with international energy security principles and could further increase the region's supply capacity. However, the radical mood of the Iranian leadership and political elite, the growing international pressure on Iran, limits the possibilities of such projects, and this is sometimes in the interests of geopolitical competitors and is also the subject of geopolitical competition in the Persian Gulf. In general, the region's supply potential is high.

The issue of supply is also a key issue in ensuring energy security in the Caspian and Central Asian regions. Experts estimate that the oil fields in the Caspian Sea contain 24-26 billion tons, or $10 \%$ of the world's reserves, and 8,300 billion cubic meters of gas. forms a cube. Central Asian states also have the potential to play a role in global energy policy. Uzbekistan and Turkmenistan have large gas reserves, and Kazakhstan has many oil and gas reserves, and energy resources are being exported along the existing transport corridors. The intensification of the geopolitical competitive environment in the region also affects the definition of foreign energy policy of the region. This in turn affects the guaranteed supply. Over the years, Central Asian states have exported their oil and gas resources only in a northerly direction through energy systems inherited from the former regime. As a result of recent interstate geopolitical interests, a number of achievements have been made in energy cooperation. In particular, the launch of the Turkmenistan-China gas pipeline, the ongoing negotiations on the Trans-Afghan gas pipeline and other projects show that the countries of the region are becoming subjects of global energy policy, reliable suppliers.

Problems such as safe transport - safe supply of oil and gas resources to the consumer, ensuring the continuity of resource flows in supply processes, prevention of losses in quality and volume are another important 
element of energy security - increasing the importance of transport safety. At the same time, it has become the "most active" problem involved in modern geopolitical processes. The fact that the main energy resources, especially oil and gas, and the geographical location of producers are located at a certain distance from consumers, the supply of oil and gas by land in pipelines or waterways in tankers shows the relevance of this particular factor of energy security. And it in turn reflects its geopolitical aspects.

Land transport by tankers through oil and gas pipelines and waterways is the main means of ensuring the safe transportation of oil and gas resources. In this regard, Central Asian energy resources are mainly exported to the energy market through pipelines. According to the data, the total length of pipelines in Central Asia reaches 40 thousand $\mathrm{km}$. Of these, 27.5 thousand $\mathrm{km}$ are gas pipelines and 12.5 thousand $\mathrm{km}$ are oil pipelines.

The inconsistency of approaches to energy supply in the foreign policy of the countries in the region has a negative impact on the qualities of a reliable supplier in the region. It is precisely overcoming this geopolitical crisis and establishing mutually beneficial geoeconomic cooperation that will help increase the position of the region's countries in the world energy market. In particular, in the future, the huge resources and economic potential of Central Asian countries should be open to Russia, as well as to Afghanistan, Japan, the United States, the European Union, China and India, and other countries. Such an approach should be based on business logic. In particular, by focusing on energy importers, it is possible to create competition between China, Japan, India and other countries that need hydrocarbons, and as a result create huge opportunities for Central Asian countries to transport oil and gas resources. But there is another side of the issue, which is to ensure the security of energy supplies from the region, and to pay attention to these aspects in future projects. For example, more than $800 \mathrm{~km}$ of the Trans-Afghan gas pipeline project must pass through Afghanistan. In the context of chaos and political instability in Afghanistan, it is difficult to find a clear solution to the problem of timely and quality delivery of products to consumers.

The issue of transport safety is one of the most pressing issues for the Gulf Arab states and the entire Middle East region. The recent events on this issue and its negative consequences urge the countries of the region to pay serious attention to the issue of security.

The current oil embargo, the 1973 oil crisis, the 1979 Iranian revolution, the 1981 Iran-Iraq Tanker War (military strikes on more than 500 oil tankers), resulting in the mass deployment of U.S. troops in the region, 1990 The IraqKuwait majorities of 1991 had a significant impact not only on the energy balance in the Persian Gulf but also on international energy security.

Currently, 40-50 million barrels of oil per day, ie $60-70 \%$ of the world's oil is transported by tankers across the oceans. $50 \%$ of the oil extracted in the world is delivered to consumers through the Straits of Hormuz, Malacca and Bab al-Mandab. At the same time, these routes are the most dangerous transport routes.In particular, the Strait of Hormuz is the most worrying waterway for the world oil market, as a corridor connecting the Persian Gulf and the Arabian Sea, from which 17 million barrels of oil per day are transported. It accounts for $35 \%$ of oil trade by sea and $93 \%$ of the exports of all Gulf states. In addition, the Strait of Hormuz supplies 3.5 billion cubic meters of liquefied natural gas 
per day to Asia, Europe and North America. Experts say closure of the Strait of Hormuz could lead to a $\$ 250$ increase in oil prices.

While the delivery of oil and gas resources by tankers is much cheaper, it is one of the most dangerous means from a security point of view. In particular, as a result of catastrophic events, firstly, there is a disruption of reliable and uninterrupted supply, secondly, there is serious damage to the environment, and thirdly, there is an impact on international energy security. In addition, waterway problems can also lead to interstate political and military conflicts.

\section{CONCLUSIONS}

In conclusion, the concept of energy security consists of such components as energy resources, price, supply and transport security, which should be approached in terms of its components. Energy security is not only determined by indicators such as the depletion or non-availability of energy resources, rising prices. In this context, the energy security of different states or groups of states, regions can be defined differently.

In particular, the energy security of exporting countries is determined by stable reserves, diversity of supply opportunities and protection from internal and external threats to their position in the world energy market. The energy security of energy-importing countries is determined by the availability of opportunities to purchase energy resources at low prices and energy cooperation in alternative directions.

Thus, energy security should be understood as the reserves of energy resources that ensure the sustainable development of countries, their ability to sell and buy, the transit potential of countries, protection from internal and external threats to safe and alternative routes of energy transportation.

\section{REFERENCES}

1. Belgrave R,. Ebinger Ch. K., Okino $\mathrm{H}$. (1987). Energy Security to 2000 . Aldershot: Gower, P.2.

2. Bielecki J. (2002). Energy security: is the wolf at the door? // The Quarterly Review of Economics and Finance,Vol. 42, Issue 2, P.237.

3. Borovskiy Yu. Politizatsiya mirovoy energetiki // Mejdunarodniye protsessi.2008.Yanvar

aprel.T.6.№1(16).URL:http://www.inter trends.ru/sixteenth/002.htm

4. Gafurov A.R. (2010) . Suщnost kategorii "energeticheskaya bezopasnost" i yee mesto $v$ obщеy strukture bezopasnosti // Vestnik MGTU,Tom 13, №1, S.178-182.

5. Harris S. (2010). Global and Regional Orders and the Changing Geopolitics of Energy // Australian Journal of International Affairs, Vol 64, No.2, April., p.169.

6. Jiznin S.Z. (2005). Energeticheskaya diplomatiya Rossii. - M., S.42, 44, 47, 48.

7. Azimov, H. Y. (2019). THE PROBLEM OF MORO MUSLIMS. Theoretical \& Applied Science, (6), 519-521.

8. Ravshanovich, R. F., Tuigunovich, R. F., \& Yakubovich, A. H. (2020). Amir Temur and Turan States. Bulletin Social-Economic and Humanitarian Research, (5 (7)).

9. Kalicki H., David L. (2005). Energy and Security: Toward a New Foreign Policy Strategy. - Goldwyn Washington Baltimore: Woodron Center Press, John Hopkins University Press, P.25 
10. Karimov I.A. (2006). Inson, uning huquq va erkinliklari - oliy qadriyat. T.14. - T.:O‘zbekiston, B.106.

11. Kokoshin A.A. (2006).Mejdunarodnaya energeticheskaya bezopasnost. - M., s.80.

12. Azimov, H. Y. (2019). The emergence of the Syrian crisis and the impact of the external forces on it. Bulletin Social-Economic and Humanitarian Research, (4), 92-97.

13. Milov V.S. (2004). Na isxode neftyanoy eri// Rossiya $v$ globalnoy politike, № 4, iyul-avgust, S.23.

14. Sentralnaya Aziya - 2010, perspektivi chelovecheskogo razvitiya. - UNDP, S.29.

15. Азимов, Хабибулло Якубович.(2020). Сурия инқирози даврида ТуркияРоссия муносабатлар. Imom Buxoriy saboqlari 1 (2), 86-88.

16. Yergin D. (2006). Ensuring Energy Security//Foreign Affairs. Volume 85, No.2, March /April, p.81.

17. Turaev, A. (2020). Минтақавий энергетик хавфсизлик: генезиси ва мохияти. Архив Научных Публикаций JSPI, 2(1). извлечено от https://science.i-

edu.uz/index.php/archive_jspi/article/v iew/96

18. Turaev, А. (2020). Форс куурфазида минтақавий энергетик хавфсизликни таъминлаш муаммолари. Архив Научных Публикаций JSPI, 22(1). извлечено от https://science.iedu.uz/index.php/archive jspi/article/v iew/1876

19. Turaev, A. (2020). Ташқи энергетик сиёсат ва энергетик дипломатия. Архив Научных Публикаций JSPI, 22(1). извлечено от https://science.iedu.uz/index.php/archive jspi/article/v iew/1877
20. Turaev, А. (2020). Марказий Осиёда энергетик хавфсизликни таъминлашнинг ўзига хос хусусиятлари · Архив Научных Публикаций JSPI, 1(38). извлечено от https://science.i-

edu.uz/index.php/archive_jspi/article/v iew/5963

21. Turaev, A. (2020). Нефть -газ сохасида энергетик хавфсизликни таъминлашнинг минтақавий жихатлари - Архив Научных Публикаций JSPI, 1(38), 1/11. извлечено от https://science.iedu.uz/index.php/archive jspi/article/v iew/5957

22. Turaev, А. (2020). Инсон, табиат ва геосиёсий манфаатлар . Архив Научных Публикаций JSPI, 1(38). извлечено от https://science.iedu.uz/index.php/archive _jspi/article/v iew/5960

23. Turaev, A. (2020). Минтақавий энергетик хавфсизлик тадқиқининг методологик масалалари. Архив Научных Публикаций JSPI, 1(38). извлечено от https://science.iedu.uz/index.php/archive_jspi/article/v iew/5814

24. Turaev, A. (2020). Энергетик хавфсизликни таъминлашда нефтьгаз ресурслари омили . Архив Научных Публикаций JSPI, 1(38). извлечено от https://science.iedu.uz/index.php/archive jspi/article/v iew/5959

25. MUHAMMADSIDIKOV, $M$. ÖZBEKISTAN'DA TOPLUMSAL YAŞAMIN ANA ÖZELLiči HOŞGÖRÜ. Atatürk Üniversitesi Sosyal Bilimler Dergisi, (54), 7-14.

26. Мухаммадсидиков, М. (2009). Религиозная толерантность как главная черта общественной жизни 
Узбекистана. Вестник Челябинского государственного университета, (40).

27. Muhammadsidiqov, M. (2015). Stability of North African Region. Int. J. of Multidisciplinary and Current research, 3.

28. Mukhammadsidiqov, M. (2020). The importance of regulating the relationship between the state and religion in ensuring the stability of society. The Light of Islam, 2020(2), 12-

17.

29. Muhammadsidiqov, M. (2018). The influence of "religious factor" on ethno-political and confessional conflicts in muslim countries. The light of islam, 2018(1), 18.

30. Mukhammadolim, M. (2019). PROBLEMS OF REGULATION OF SECULARISM AND RELIGIOUS PRINCIPLES IN ARAB COUNTRIES. Bulletin Social-Economic and Humanitarian Research, (4 (6)).

31. Азимов, Х.Я. (2020). Кашмир муаммоси: тарих ва бугун. КарДУ ХАБАРЛАРИ, (1), 180-185.

32. Mukhammadsidiqov, M. M. (2019). THE DEVELOPMENT OF ENERGY SECTOR IN CENTRAL ASIA AND THE ROLE OF UZBEKISTAN IN IT. Theoretical \& Applied Science, (6), 532-534.

33. Mukhammadsidiqov, Mukhammadolim and Turaev, Abrar (2020) "INFLUENCE OF US NEOCONSERVATISM ON FORMATION OF NATIONAL SECURITY PARADIGM," The Light of Islam: Vol. 2020 : Iss. 3 , Article 12. Available at: https://uzjournals.edu.uz/iiau/vol2020/i $\mathrm{ss} 3 / 12$ 